Jan SANDNER

IEiB WFCh UKSW Warszawa

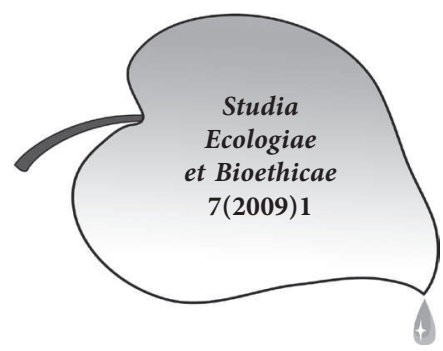

\title{
Wybrane aspekty metodyki badań holistycznej edukacji środowiskowej w świetle idei zrównoważonego rozwoju
}

Koncepcja idei zrównoważonego rozwoju, stała się przyczynkiem do nowego spojrzenia na problemy w obszarze metodyki badawczej edukacji środowiskowej. Nie ma możliwości skutecznego rozwijania „świadomości ekologicznej” bez równoległego rozwoju nauk badających zjawiska przyrodnicze. Rozwój ten, powinien jednak się odbywać przy wyraźnej stymulacji płynącej z filozoficznego podejścia do świadomości ekologicznej, jako części świadomości społecznej. Sama „świadomość ekologiczna” do dziś, nie doczekała się zdefiniowanej ostatecznie kategorii socjologicznej. Dodatkowym problemem we wszelkiego typu analizach jest również określenie platformy odniesienia dla świadomości ekologicznej. Czy będzie to świadomość jednostki, czy też grupy społecznej? Ponieważ „świadomość ekologiczna” jest w wymiarze jednostkowym w pewnym stopniu rezultatem procesu socjalizacji, należałoby więc badać indywidualną świadomość ekologiczną poszczególnych osób.

„Świadomość ekologiczna" ma również stanowić podstawowy element kategoryzujący dla koncepcji idei zrównoważonego rozwoju. Sposób, w jaki będzie prowadzona ta kategoryzacja, uzależniony jest od procesu edukacji środowiskowej. Zdefiniowanie spójnej metodologii, opierającej się na jak najszerszym, interdyscyplinarnym podejściu do elementów środowiska przyrodniczego jest kluczowe w kształtowaniu procesu edukacji środowiskowej. Potrzeba holistycznego podejścia jest już coraz powszechniej akceptowana, ale nie zawsze tak samo rozumiana, przez różne grupy badaczy. Na poziomie tworzenia definicji, mniej lub bardziej holistycznych, nie skutkuje to większymi problemami. Inaczej jest w momencie, kiedy należy stworzyć zamkniętą metodykę badawczą, opierającą się na konkretnych rozwiązaniach holistycznych. Wtedy to dochodzi do wielu nieporozumień prowadzących do konfliktów w efekcie blokujących rozwój podstaw naukowych dla idei zrównoważonego rozwoju. Konsekwencją tego procesu jest, nie tylko trudność w rozumieniu współcześnie zachodzących zjawisk środowiskowych, ale również ich kształtowanie w myśl idei zrównoważonego 
rozwoju. Poprzez kształtowanie w tym wypadku, należy rozumieć zarządzanie nimi, doprowadzając do daleko idącej równowagi pomiędzy naturą, a człowiekiem. Proces zarządzania środowiskiem, wyłania się nam jako konsekwencja idei zrównoważonego rozwoju. Nie ma możliwości samodzielnego rozwoju idei zrównoważonego rozwoju, bez podejmowania równolegle świadomych działań w kierunku systemowych metod wdrażania zarządzania środowiskiem przyrodniczym. Proces zarządzania środowiskiem przyrodniczym jest natomiast, uzależniony od postępu w holistycznej edukacji środowiskowej ${ }^{1}$. Wszystkie te powiązania świadczą o istotnym skomplikowaniu, całego tego procesu. Dopóki poruszamy się w sferze idei, można formułować dość spójne zamknięte modele środowiskowe. Inaczej jednak wygląda sytuacja w momencie, kiedy trzeba te dotychczas teoretycznie funkcjonujące modele środowiskowe, dostosować do konkretnych oczekiwań potencjalnych użytkowników (jednostek, czy grup społecznych). Jest to problem, który nie tylko dotyczy metodyki konkretnych rozwiązań środowiskowych, ale również procesu edukacji środowiskowej. Analizując procesy środowiskowe, które zachodzą w skali globalnej, należy również badać w podobnej skali. Wymusza to nowe jakościowo podejście do środowiska, bynajmniej jednak, nie zrywające z przyjętą metodyką badawczą obowiązującą w naukach przyrodniczych.

W Instytucie Ekologii i Bioetyki UKSW w roku akademickim 2006/2007 podjęty został projekt, którego celem było opracowanie metod estymacji stanu przyrodniczej edukacji holistycznej. Badania te miały na celu, między innymi wypracowanie nowych rozwiązań systemowych, które można by wprowadzić do programów nauczania akademickiego na kierunkach o specjalności Ochrona Środowiska. Opracowując metody estymacji w zakresie stanu przyrodniczej edukacji holistycznej, oparto się na przedstawionych wcześniej rozwiązaniach, pochodzących przede wszystkim z nauk ekologicznych oraz wiedzy zgromadzonej w ramach innych nauk, tzn. ekofilozofii, geologii, hydrologii, gleboznawstwa, czy geochemii.

Przeprowadzenie zaplanowanych badań w zakresie problematyki holistycznej edukacji środowiskowej w świetle idei zrównoważonego rozwoju, związane jest przede wszystkim ze zdefiniowaniem „obszaru” badawczego oraz metod estymacji. Etap ten, wiąże w sobie znaczną ilość problemów merytorycznych. Wśród najistotniejszych z nich, należy wymienić następujące:

- określenie granicy pomiędzy poziomami mereologicznym oraz holistycznym,

- merytoryczny dobór problematyki badawczej (w ramach istniejących dziedzin nauki),

1 J. SANDNER, Wybrane aspekty procesów środowiskowych holistycznej edukacji przyrodniczej w świetle idei zrównoważonego rozwoju, Problemy Ekorozwoju, vol. 3, Nr 2, s. 69-80, 2008. 
Wybrane aspekty metodyki badań holistycznej edukacji środowiskowej w świetle idei...

- określenie podstawowej przyrodniczej jednostki odniesienia,

- zdefiniowanie roli ekosystemu w układzie holistycznym,

- wybór sfer badawczych dostosowanych do układu, w którym zachodzi ciągły przepływ materii i energii,

- dobór problematyki badawczej, uwzględniającej pełną wiedzę o środowisku (w tym zasadę brzytwy Williama Occam’a) w ramach sfer badawczych,

- określenie rangi i stosunki wzajemne wybranych sfer badawczych,

- sposób interpretacji otrzymanych wyników (dobór właściwych metod statystycznych).

$\mathrm{W}$ realizacji niniejszej pracy, jedną z podstawowych decyzji, była kwestia doboru układu odniesienia tzn. przyrodniczej jednostki odniesienia. Przyrodniczą jednostką odniesienia, został wybrany ekosystem. Ekosystem wydaje się być układem najwłaściwszym ze względu na swoją rolę, jaką pełni w środowisku. Ekosystem jest układem, który można w dodatku stosunkowo precyzyjnie zdefiniować na podstawie przepływu energii i materii. Jest to szczególnie ważne przy badaniu zjawisk w ramach samych układów.

Określenie jednostki podstawowej jest punktem wyjścia do dokonania analizy roli ekosystemu w układzie holistycznym oraz wydzielenia praktycznej granicy, pomiędzy poziomami mereologicznym oraz holistycznym. Jest to szczególnie ważne w momencie, gdy budowany jest cały układ pojęć opisujący zjawiska przyrodnicze na poziomie systemowym. Prawidłowy wybór tych poziomów, określenie rang ważności oraz dostosowanie do nich odpowiedniej problematyki badawczej zgodnej, między innymi z zasadą brzytwy Williama Occam’a stanowi o prawidłowym zdefiniowaniu niniejszej problematyki w ujęciu holistycznym.

W pracy tej ostatecznie zostało wybranych 9 sfer badawczych, do których zaliczono:

1. pojęcia systemowe $\mathrm{w}$ zakresie pedosfery,

2. pojęcia systemowe w zakresie atmosfery,

3. pojęcia systemowe $\mathrm{w}$ zakresie litosfery,

4. pojęcia systemowe globalne w zakresie Ziemi,

5. pojęcia systemowe w zakresie mórz i oceanów,

6. pojęcia systemowe $\mathrm{w}$ zakresie działalności człowieka na systemy środowiskowe,

7. pojęcia systemowe w zakresie stabilności systemów środowiskowych,

8. pojęcia systemowe $\mathrm{w}$ zakresie ekologii,

9. pojęcia systemowe w zakresie pojęć o charakterze globalnym.

Badania zostały przeprowadzone wśród studentów III roku w Instytucie Ekologii i Bioetyki UKSW na specjalności Ochrona Środowiska poprzez Internet w oparciu o specjalnie do tego celu zainstalowany i skonfigurowany system do e-learningu. System ten posłużył do przygotowania testów technikami on-line w uznanych standardach międzynarodowych. 
Pod pojęciem e-learning (e-edukacja), należy rozumieć zastosowania różnych informatycznych narzędzi do wspomagania procesu nauczania, które bazują na sieci komputerowej, są dystrybuowane przez tą sieć, lub dostosowywane do sieci. W zdecydowanej większości zastosowań siecią tą jest Internet. W chwili obecnej rozróżnia się trzy rodzaje systemów informatycznych o różnej funkcjonalności, tworzących platformy dla e-edukacji. Są to systemy klasy LMS (Learning Management System), LCMS (Learning Content Management System) oraz VCS (Virtual Classroom System).

W niniejszej pracy, został wykorzystany system, klasy LMS oraz LCMS. Interaktywny system e-learning posłużył, nie tylko do realizacji samych badań, ale również do przeprowadzenia podstawowych obliczeń statystycznych. Rezultaty badań w formie arkuszy danych, zostały przeniesione do programu komputerowego Numbers, gdzie zostały poddane obróbce matematyczno-statystycznej. Wyniki zostały opracowane pod kątem potrzeb realizowanego projektu. Sposób, w jaki zestawiono otrzymane rezultaty, umożliwia przeprowadzenie daleko idących analiz wiedzy, między innymi w zakresie umiejętności kojarzenia faktów, znajomości pojęć, czy też rozumienia całych procesów przyczynowo-skutkowych wśród badanej grupy studentów. Wszystkie bloki merytoryczne, które były monitorowane łącznie, zawierają 105 samodzielnych modułów badawczych. Każdy z tych modułów, był niezależnie monitorowany, a następnie przy zastosowaniu odpowiedniej procedury wagowo oceniany. W niniejszej pracy, zastosowane rozwiązania informatyczne, były jedynie technicznym narzędziem do precyzyjnego przeprowadzenia badania.

Analiza merytoryczna przebiegu całego procesu oceny wyników holistycznej edukacji środowiskowej, została przeprowadzona z zastosowaniem tej samej metodyki, która powinna obowiązywać w procesie realizacji systemowej edukacji środowiskowej z uwzględnieniem założeń wynikających z idei zrównoważonego rozwoju.

Wskazanie nowych kierunków rozwoju procesu holistycznej edukacji środowiskowej, powinno stać się przyczynkiem na drodze systemowych działań prowadzących do lepszego poznania środowiska przyrodniczego, a tym samym do powstrzymania niekorzystnych procesów powodujących jego degradację. Ogromną rolę w tym procesie, powinny również odgrywać nauki humanistyczne. ${ }^{2}$ Nauki te powinny, przede wszystkim skupić się na problematyce kształtowania świadomości oraz postaw pro-ekologicznych. W dziedzinie tej, istnieją bardzo znaczące zaniedbania w naszym kraju. Związane jest to $\mathrm{z}$ naszą historyczną przeszłością polityczną, ale również $\mathrm{z}$ brakiem radykalnych reform w sposobie nauczania problematyki ochrony środowiska. Kształtowanie postaw pro-ekolo-

2 W. Tyburski, Powstanie i rozwój filozofii ekologicznej, Problemy Ekorozwoju, Lublin, vol. 1, Nr 1, s. 7-15, 2006. 
Wybrane aspekty metodyki badań holistycznej edukacji środowiskowej w świetle idei...

gicznych, może odbywać się jedynie w społeczeństwach, które prowadzą świadomą i systematyczną edukację z uwzględnieniem problematyki holistycznej edukacji środowiskowej. Wyniki przeprowadzonych badań dowodzą, nie tylko braku merytorycznej wiedzy holistycznej o środowisku, ale również i samej świadomości pro-ekologicznej. Oczywiście pod pojęciem świadomości, można rozumieć bardzo wiele znaczeń. Dla jednych jest to wiedza o środowisku, dla innych może to być produkcja zdrowej żywności, czy też zdrowy tryb życia, lub zupełnie inne zagadnienia. Wielość podejść do tego pojęcia jest porównywalna z rozumieniem innych pojęć $\mathrm{z}$ innej problematyki, mianowicie marketingu. W tej dziedzinie wiedzy jest dość podobna sytuacja. Dlatego też, wszelkie badania oraz uzyskane wyniki, dotyczące problematyki postaw pro-ekologicznych są z merytorycznego punktu widzenia, całkowicie ze sobą nieporównywalne, co negatywnie wpływa na ich wartość naukową. $Z$ tego też powodu jest to problematyka, niechętnie podejmowana przez badaczy, ze względu również na swój interdyscyplinarny charakter. Ta interdyscyplinarność z jednej strony jest jej siłą poznawczą z drugiej jednak strony, silnie ją hamuje. Spowodowane jest to między innymi, daleko idącą ogólnością sformułowań, odmiennym naukowym warsztatem badań, stosowaną terminologią oraz celami dla jakich, powstają te prace.

Z dotychczas przeprowadzonych badań wynika z pewnością, że głównym czynnikiem hamującym jest znikoma wiedza $\mathrm{z}$ zakresu rozumienia podstawowych pojęć środowiskowych oraz zachodzących w środowisku procesów. Brak naukowych opracowań, podejmujących metodykę holistycznej edukacji środowiskowej, przyczynia się również pośrednio do stanu świadomości pro-ekologicznej społeczeństw. Wypracowanie ujednoliconej metodyki w zakresie holistycznej edukacji środowiskowej, filozofii ekologicznej i etyki środowiskowej, powinno w efekcie wpłynąć, nie tylko na stan wiedzy w zakresie tej problematyki, ale również stworzyć w przyszłości merytoryczne podstawy do realizacji badań procesu kształtowania postaw pro-ekologicznych.

Metodyka ta, powinna wyrastać ze stylu myślenia Aldo Leopolda (ojca filozofii ekologicznej i etyki środowiskowej) dla którego przyroda powinna być traktowana, jako całość, a nie wybrane oderwane od siebie obszary. ${ }^{3}$ Powinna, być wartością samą $\mathrm{w}$ sobie z prawem do samodzielnego istnienia i trwania we właściwej sobie postaci, bez względu na potrzeby człowieka. Człowiek powinien ten stan w pełni uszanować, a co najważniejsze go respektować. System ochrony przyrody według Aldo Leopolda, nie powinien opierać się wyłącznie na korzyściach gospodarczych, ignorując w ten sposób inne elementy środowiska, nie mające walorów utylitarnych, a będące niezbędne dla prawidłowego funkcjo-

\footnotetext{
A. LEOPOLD, A sand county almanac and sketches here and there, 1949, przekład; Zapiski z piaszczystej krainy, przedmowa, Okraska-Bystrak, Bielsko-Biała 2004, za W. TYвURsкi, Problemy Ekorozwoju, nr 1, 2006.
} 
nowania całości środowiska. Zaprezentowane podejście, dało początek myśleniu holistycznemu o środowisku przyrodniczym. Szczególną rolę dla dalszego kształtowania, tych poglądów odegrał filozof Holmes Rolston III. Jego konstrukcja myślenia, uwzględnia rolę odpowiedzialności człowieka za środowisko na tle naturalistycznej koncepcji etyki środowiskowej. Wskazywał na prymat dobra funkcjonowania całych ekosystemów nad dobrem indywidualnym. ${ }^{4}$ Wyższość tego prymatu, przedłożył w postaci koncepcji etyki biznesu w stosunku do środowiska przyrodniczego. Problemy, które tkwią w tych relacjach są w wielu miejscach wspólne z problemami w ramach idei zrównoważonego rozwoju. Ten sposób interpretacji w stosunku do środowiska przyrodniczego jest zgoła różny w stosunku do biocentrycznie zorientowanej etyki środowiskowej. Etyki, dla której problemy środowiska, jako całości są postrzegane poprzez pryzmat bytów jednostkowych. Systemowe poznanie środowiska przyrodniczego, poprzez pryzmat bytów jednostkowych, nie jest możliwe. Nie powinno więc być możliwe, również prawidłowe zdefiniowanie potrzeb jednostkowych, które gwarantowałyby normalny rozwój danego organizmu. Nie jest to możliwe, ponieważ żaden organizm, nie funkcjonuje samodzielnie, choć zawsze pełni jakąśs rolę w systemie współzależności. Sposób, w jaki jest uzależniony od innych elementów biotycznych i abiotycznych środowiska warunkuje jego egzystencję. Dlatego też podejście holistyczne w tworzeniu podstaw metodycznych dla holistycznej edukacji środowiskowej, wydaje się być w pełni uzasadnione. Oczywiście od strony etycznej podejście biocentryczne, niesie ze sobą określone niezbywalne wartości moralne. Wartości te jednak, zawsze pozostaną w sferze pojęć empirycznie niemierzalnych.

W idei zrównoważonego rozwoju, znacznie wyraźniej przebija się myślenie antropocentryczne. Wszystkie procesy środowiskowe, rozpatrywane są tutaj pod kątem potrzeb człowieka. Wśród tych procesów na pierwszy plan, wysuwają się wpływy antropogeniczne oraz kwestie dostępności zasobów ziemskich dla przyszłych pokoleń. Takie podejście ogranicza kwestie etyczne do potrzeb człowieka. Ograniczoność takiego podejścia, nie sprzyja również budowaniu podstaw metodyki dla systemowej edukacji środowiskowej. System ten, nie powinien się wyłącznie opierać na przesłankach, czy określone działania w stosunku do środowiska przyrodniczego są dla niego korzystne, czy też nie są korzystne oraz, czy są zgodne z system norm, które chronią wyłącznie ludzkie prawa. Ograniczenia sformułowane w podejściu antropocentrycznym są widoczne $\mathrm{w}$ wielu dziedzinach działalności ludzkiej. Obecny stan wiedzy społeczeństw o środowisku przyrodniczym z pewnością ten proces pogłębia. Podejście antropocentryczne, które ciągle widoczne jest w wielu działaniach na rzecz edukacji środowiskowej, skutkuje konkretnymi konsekwencjami w dążeniu do jego pełnego poznania.

4 H. Rolston III, Environmental Ethics, Wydawnictwo Temple University Press, s. 408, 1989. 
Wybrane aspekty metodyki badań holistycznej edukacji środowiskowej w świetle idei...

Nowe myślenie o środowisku przyrodniczym, wnosi ekologia głęboka. Niesie ona ze sobą tak zwaną erę „Zielonej polityki”, dla której głównym kierunkiem działania jest ochrona bogactwa i różnorodności. Ten sposób interpretacji i postrzegania środowiska przyrodniczego jest z pewnością dla niego korzystny. Umocowanie głównych zasad tego nurtu na wiedzy zaczerpniętej z ekologii z pewnością jest czynnikiem, który powoduje nowe spojrzenie na relacje środowiskowe, pomiędzy przyrodą a człowiekiem. W relacjach tych, zaczęto dostrzegać, potrzeby innych organizmów, ich rolę w systemie współzależności oddziaływania na siebie gatunków. Wśród filozofów, głównym propagatorem tego nurtu, był Norweg Arne Naess. ${ }^{5}$ Myśl ta, nie mogłaby powstać oraz dalej się rozwijać, bez istotnego udziału również wybitnych biologów, czy ekologów. Wielu z nich, dostrzegało głębokie relacje środowiskowe, pomiędzy człowiekiem a środowiskiem.

W latach siedemdziesiątych w naszym kraju, pomimo daleko idącym niesprzyjającym warunkom politycznym, jakie wtedy panowały, ukazało się kilka znaczących pozycji książkowych, podejmujących tę „niemile widzianą” problematykę. Jedną z najważniejszych z nich, była książka prof. dr. hab. Henryka Sandnera, pt. Człowiek i przyroda. ${ }^{6}$ Autor odważył się w niej wskazać na problemy harmonii i dysharmonii, między naturą i działalnością człowieka. Odniósł się również do narastającego, negatywnego wpływu cywilizacji technicznej na środowisko. Poruszył w niej, także problematykę relacji środowiskowych, ale od strony funkcjonowania łańcuchów troficznych. Ten sposób, postrzegania relacji środowiskowych z pewnością przyczynił się do dalszego rozwoju, nie tylko samej ekologii, ale również innych nauk, opierających swoje eksperymenty na podobnych założeniach metodycznych.

Podejście do metodyki holistycznej edukacji środowiskowej jest w pewnym sensie zbieżne z myśleniem holistycznym, reprezentowanym w ekologii głębokiej. Wspólną platformą dla tego podejścia jest przede wszystkim, już samo ujęcie holistyczne środowiska przyrodniczego. Zwolennicy, takiego podejścia wskazują, że jest to jedyna droga powstrzymania, postępującego globalnego kryzysu ekologicznego. Holistyczne podejście do tych problemów, powinno pomóc w budowaniu świadomości społecznej oraz ostatecznym odrzuceniu czysto technokratycznego podejścia do środowiska przyrodniczego. Kształtowanie świadomości proekologicznej, powinno oprzeć się na wiedzy w zakresie istnienia wzajemnych zwrotnych relacji środowiskowych. $\mathrm{W}$ tym wypadku bynajmniej jednak, nie powinno chodzić jedynie o układy opierające się na piramidzie troficznej, ale również pozostałych relacjach środowiskowych, dla których punktem odniesienia byłby ekosys-

\footnotetext{
5 A. NaEss, Ecology, Community and Lifestyle, Wydawnictwo Cambridge University Press, s. 223, 1993.

6 H. Sandner, Człowiek i przyroda, Wiedza Powszechna, wyd. I, Warszawa, s. 273, 1972.
} 
tem. Jest to rozwiązanie, które łączy w sobie nie tylko rezultaty badań opierających się na empirii, ale również wynikające z przemyśleń samej ekofilozofii. Rzecz toczy się przecież o naszą świadomość ekologiczną. Świadomość, na którą składa się koncepcja poznania świata, między innymi poprzez swoją interdyscyplinarność. Nabranie odpowiedniej perspektywy do tego podejścia, poprzez ujęcie procesów środowiskowych w systemie holistycznym jest najbliższe procesowi kształtowania świadomości ekologicznej. Bez świadomości ekologicznej, nie ma mowy, ani o wdrażaniu idei zrównoważonego rozwoju, jak i ich dalszym kształtowaniu w miarę, postępującego równolegle procesu, dalszej antropogenizacji środowiska przyrodniczego. Odwrócenie tych tendencji, możliwe jedynie będzie w momencie, gdy zostaną w naszej świadomości uruchomione wartości o odpowiedzialności za własne życie, a także życie przyszłych pokoleń oraz za środowisko w którym żyjemy, zgodnie z zasadą aksjologicznej etyki ekologicznej.

Według Skolimowskiego w myśl ewolucyjnego charakteru rzeczywistości głównym celem człowieka, nie powinna być bynajmniej chaotyczna eksploatacja wszystkich zasobów Ziemi, ale wręcz przeciwnie, rozumne działanie prowadzące do zachowania i wzmacniania tego wszystkiego, co istnieje. Ten sposób widzenia rzeczywistości, chyba najbardziej oddaje kierunek, w którym powinniśmy zmierzać, poszukując konkretnych rozwiązań dla metodyki edukacji środowiskowej. Jest to sposób widzenia środowiska, jego potrzeb, poprzez pryzmat holistycznych procesów środowiskowych w nim zachodzących. Dysponując tymi przemyśleniami oraz doświadczeniem, które wnieśli kolejni badacze tej problematyki, można powiedzieć, że zasadnicze kierunki dla samej myśli oraz roli jaką ma ona odegrać w kształtowaniu idei zrównoważonego rozwoju, nie ma już chyba nikt większych wątpliwości. Świadomość ekologiczną z pewnością należy kształtować, pozostaje jednak ciągle pytanie, jak od strony metodycznej, należy ten proces realizować? Jak od strony metodycznej potraktować, tak szeroką interdyscyplinarność tego zagadnienia? Gdzie, należałoby postawić granice dla poznania holistycznego, procesów odpowiedzialnych za przepływ energii i materii odbywający się w ramach ekosystemów? Wreszcie, jaką rolę, powinna odegrać ekofilozofia, jako element spójny w budowaniu idei zrównoważonego rozwoju?

Przytoczone pytania, stanowią jedynie wybrane przykłady problemów, przed którymi stoi nie tylko sama nauka, ale również społeczeństwa, które wcześniej czy później, będą musiały na nie odpowiedzieć, chcąc w dalszym ciągu skutecznie rozwijać idee zrównoważonego rozwoju. Rozwiązanie nawet niektórych zagadnień wchodzących w skład postawionych pytań, powinno być kontynuowane stopniowo w miarę rozwoju nauk podstawowych przyrodniczych o Ziemi oraz ekofilozofii. Prawdopodobnie, będzie to proces dość długotrwały, uzależniony, między innymi od postępów w procesie wdrażania holistycznego systemu edukacji środowiskowej. 
Wybrane aspekty metodyki badań holistycznej edukacji środowiskowej w świetle idei...

Uruchomienie procesu wdrażania nowego systemu edukacji środowiskowej, nie będzie jednak możliwe bez wcześniejszego wypracowania właściwej metodologii oraz odpowiedniej metodyki badawczej. Metodyka ta, powinna umożliwiać przeprowadzenie dowolnych analiz uzyskiwanych efektów, realizowanego procesu kształcenia środowiskowego. Metodyka ta, nie tylko powinna być dostosowana do tego procesu, ale również co jest nie mniej ważne odpowiednio wyprzedzać cały proces konstruowania systemu holistycznej edukacji środowiskowej. Proces ten więc, nie powinien stanowić jedynie kolejnego zbioru założeń analitycznych, które nie będą mieć oparcia w żadnych praktycznych działaniach. Proces ten powinien mieć, jak najbardziej charakter konstruktywny. Filozofia skierowana ku ocaleniu, musi być filozofią konstruktywną, a nie tylko analizą. ${ }^{7}$ Musi przynieść również konkretne wymierne rezultaty w procesie kształtowania świadomości ekologicznej. Jest to niezwykle ważne z punktu widzenia dalszego rozwijania idei zrównoważonego rozwoju. Brak holistycznego podejścia do edukacji skutkuje w rezultacie, nie tylko niskim stanem świadomości ekologicznej, ale również niemożnością badania wiedzy o środowisku odpowiedzialnej za ten stan.

Pierwszym etapem w budowaniu systemowego podejścia do procesu edukacji środowiskowej, powinno być zdefiniowanie sfer odpowiedzialnych za to środowisko. Etap ten okazuje się, że jest tylko z pozoru dość prosty. Każda z nauk podstawowych przyrodniczych i o Ziemi opisuje te sfery, jednak używa do tego różnego języka oraz specyficznej, charakterystycznej dla siebie metodyki badawczej. W rezultacie okazuje się, że te same sfery, mogą być nawet w sposób dość odmienny przedstawiane i opisywane w zależności od tego, kto tak faktycznie, dokonuje tego procesu poznawczego. Najczęściej różnorodność tę, obserwujemy w zależności od kierunku wykształcenia naukowca, badającego problematykę powiązaną z jego dyscypliną naukową. Prawdziwy problem powstaje w momencie, gdy badania przenoszą się na poziom bardziej interdyscyplinarny, obejmując swoim zasięgiem różne interakcje, występujące pomiędzy sferami. W tej sytuacji dotychczasowe metody badań i oceny środowiska, przestają się sprawdzać. Nie ma możliwości zastąpienia ich innymi, ponieważ tak faktycznie, nie istnieje, jak na razie żadna nauka systemowa, obejmująca swoim zasięgiem całą problematykę związaną z badaniem środowiska. Miejsce to, o czym była już wcześniej mowa, jak na razie wypełnia dość skutecznie z całym swoim „warsztatem” badawczym ekologia.

W ostatnim okresie, szczególnie w miarę rozwoju ekofilozofii, coraz wyraźniej uwidaczniają się nowe ogromne, niezagospodarowane (pod względem metodyki badawczej) obszary problemów związanych z relacjami, pomiędzy człowiekiem a naturą. Wiedza w nich zawarta, nie może być „uprawiana” w ramach

7 H. Skolimowski, Filozofia żyjaca. Ekofilozofia jako drzewo życia, Wydawnictwo Pusty Obłok, s. 106-110, 1993. 
obowiązującej metodologii badań ekologicznych ponieważ, nie jest bezpośrednio z nią związana. Inne nauki o Ziemi, czy też przyrodnicze również, nie dysponują odpowiednim warsztatem metodycznym, aby móc zająć się tą sferą zagadnień. W tej sytuacji, pozostaje bardzo duży obszar problemów środowiskowych, które nie są prawidłowo rozwijane. Najlepiej jest to widoczne, podczas konstruowania oraz wdrażania idei zrównoważonego rozwoju. Idee te w pewnym sensie, uwidoczniły w sobie, całą naszą niewiedzę na temat środowiska i procesów w nim zachodzących.

Przykładów świadczących o nieprawidłowym zarządzaniu środowiskiem (będących wynikiem tej niewiedzy), wdrażanych w świetle idei zrównoważonego rozwoju, można przytoczyć bardzo wiele. Szczególnie dużo takich błędów, popełniono chociażby zarządzając gospodarką wodną na terenie UE. ${ }^{8}$ Błędy te, dotyczą przede wszystkim krajów najbardziej rozwiniętych: Niemiec, Francji, czy też Austrii. Skutki tych błędów, nie tylko będą jeszcze widoczne przez kolejne dziesięciolecia, ale w dużej części są one już praktycznie, nie do naprawienia.

Analiza procesu podejmowania błędnych decyzji środowiskowych wskazuje, między innymi na brak holistycznej wiedzy o środowisku. Stan ten spowodowany szeregiem nawarstwiających się problemów merytorycznych, począwszy od braku systemowej edukacji środowiskowej, skończywszy na samej metodyce wdrażania systemowej edukacji środowiskowej. Istotnym problemem, który powinien zostać również podjęty, jest ciągle nie zdefiniowany zakres merytoryczny dla problematyki edukacji środowiskowej. Odwoływanie się w nim do pojęć tak ogólnych, jak Biosfera, z pewnością nie jest prawidłowe. W tej sytuacji w celu zdefiniowania podstaw metodycznych dla procesu holistycznej edukacji, stworzony został nowy model, który jedynie w części zbliżony jest w swoich założeniach metodycznych do rozwiązań zaczerpniętych z ekologii. Podstawą metodologiczną dla tego modelu, stały się więc kolejne sfery środowiskowe oraz zjawiska przepływu materii i energii poprzez ekosystemy.

W cytowanej pracy badawczej zrealizowanej na UKSW, został opracowany wzorcowy model bloków merytorycznych, odnoszących się do istniejących sfer środowiskowych. Model ten posłużył do przeprowadzenia badań w zakresie stanu wiedzy holistycznej, środowiskowych procesów systemowych oraz innych zjawisk zachodzących na poziomie ekosystemów.

Wspomniane badania zostały przeprowadzone w 2007 roku na grupie studentów III roku Uniwersytetu Kardynała Stefana Wyszyńskiego w Warszawie, studiujących na specjalności Ochrona Środowiska w Instytucie Ekologii i Bioetyki. Badania te zostały powtórzone w roku 2009 (wyniki są w trakcie opracowywania i opublikowane zostaną w 2010 roku). Ponieważ badania te, przeprowadzono

8 J. SANDNer, Environmental protection concept in holistic nature studies education, Studia Ecologiae et Bioethicae, t. 4/2006, Wydawnictwo UKSW, Warszawa, s. 377-383, 2006. 
Wybrane aspekty metodyki badań holistycznej edukacji środowiskowej w świetle idei...

w semestrze letnim, studenci dysponowali już pewną wiedzą specjalistyczną, gdyż większość programu merytorycznego w ramach trzeciego roku, została wcześniej zrealizowana. Jest to o tyle ważne, że jeszcze przed wprowadzeniem nauczania, zgodnie z systemem bolońskim na trzecim roku studiów, była realizowana większość przedmiotów specjalistycznych, tzn. przedmiotów „kierunkowych", związanych z problematyką ochrony środowiska.

Badania zostały tak zaprojektowane, aby dotyczyły przede wszystkim analizy wiedzy środowiskowej na poziomie holistycznym. Główną trudnością w tej części pracy, było określenie istniejących granic poznania, pomiędzy poziomami mereologicznym oraz holistycznym, a także merytoryczny dobór problematyki badawczej. Poziom mereologiczny najczęściej jest określany w ramach danego przedmiotu, zajmującego się określoną sferą środowiska. Wykraczanie poza bardziej lub mniej precyzyjnie zdefiniowany zakres tematyczny, najczęściej nie występuje. Uniemożliwia to zresztą sama metodyka badawcza, przyjęta w ramach poszczególnych dyscyplin. W momencie, kiedy metodyka dopuszcza poruszanie się pomiędzy badawczymi sferami, pozostaje zawsze niezdefiniowana skala systemu, którym chcemy objąć dany proces wyjaśniania zjawisk. Skala systemu, powinna być tak dobrana, aby proponowany model środowiskowy od strony formalnej, spełniał wszelkie wyobrażenia dostarczane przez rzeczywistość. Podejście takie jest niezbędne, aby móc w ogóle formułować jakieś hipotezy na temat np. stabilności, zmienności środowiska, czy też poziomu odniesienia dla holistycznej edukacji środowiskowej. Postawienie hipotezy w postaci np. nieprawidłowo realizowanego procesu systemowej edukacji środowiskowej, powinno być poprzedzone konkretnym eksperymentem, w wyniku którego zostaną zebrane niezbędne dane, poddane procedurom testującym. Dysponując dopiero takimi danymi, można przystąpić do formułowania praw, czy teorii naukowych, a następnie wyjaśniania zjawisk, sformułowanych w hipotezach naukowych. W niniejszej pracy, został zachowany wspomniany układ metodologiczny, który jest zresztą charakterystyczny również dla wielu innych badań środowiska przyrodniczego. Prawidłowo skonstruowane hipotezy, powinny dać możliwość, nie tylko formułowania warunków dla występowania określonych zjawisk, ale również wskazywać ewentualne drogi do zapobiegania lub eliminacji ewentualnych negatywnych wpływów na środowisko przyrodnicze.

W niniejszej pracy, rolę prowadzącą do eliminowania tych negatywnych wpływów, mogą wskazać uzyskane rezultaty badań. Badania te jednoznacznie potwierdzają fakt, że obecnie obowiązujący system edukacji środowiskowej w naszym kraju jest w dużym stopniu nieskuteczny. Efektem tego jest przede wszystkim niska świadomość ekologiczna, ze wszelkimi tego konsekwencjami również dla procesu kształtowania oraz wdrażania idei zrównoważonego rozwoju. Niewątpliwie wartością odpowiedzialną za wzrost świadomości jest uruchomienie procesu holistycznego myślenia o środowisku przyrodniczym i procesach 
w nim zachodzących. Dlatego też wszystkie działania metodyczne w niniejszym projekcie, zmierzały do jak najbardziej precyzyjnego, zbadania stanu wiedzy istniejących zjawisk w ujęciu systemowym. Kluczem w przeprowadzeniu tej analizy, jak już była o tym mowa wcześniej stanowiło zdefiniowanie dziewięciu sfer badawczych, które łączyłyby w sobie pod względem merytorycznym, całą problematykę środowiskową, mieszczącą się w obowiązujących specjalnościach naukowych. Zdefiniowane sfery, stały się podstawą do dalszej ich analizy pod kątem potrzeb systemowego podejścia do środowiska oraz wyboru tzw. podstawowej jednostki odniesienia. Przyrodniczą jednostką odniesienia, został wybrany ekosystem. Ekosystem wydaje się być układem najwłaściwszym ze względu na swoją rolę, jaką pełni w środowisku. Ekosystem jest układem, który można w dodatku stosunkowo precyzyjnie zdefiniować na podstawie przepływu energii i materii. Jest to szczególnie ważne przy badaniu zjawisk w ramach samych układów.

Określenie jednostki podstawowej, stało się punktem wyjścia do dokonania analizy roli ekosystemu w układzie holistycznym oraz wydzielenia praktycznej granicy, pomiędzy poziomami mereologicznym oraz holistycznym. Jest to szczególnie istotne w momencie, gdy budowany jest cały układ pojęć, opisujący zjawiska przyrodnicze na poziomie systemowym. Prawidłowy wybór tych poziomów, określenie rang ważności oraz dostosowanie do nich odpowiedniej problematyki badawczej zgodnej, między innymi z zasadą brzytwy Williama Occam’a stanowiło o prawidłowym zdefiniowaniu niniejszej problematyki w ujęciu holistycznym. Ostatecznie problematyka badawcza, została opracowana w ramach wspomnianych sfer badawczych. Dobór szczegółowych zagadnień, został zrealizowany na podstawie wcześniej przeprowadzonych rozważań naukowych. Badane problemy merytoryczne, nie stanowiły bynajmniej proporcjonalnie dobranych bloków tematycznych. Przy ich wyborze kierowano się wyłącznie kwestiami merytorycznymi. Ostateczną ich rangę i znaczenie wagowe, określono dopiero na etapie końcowego opracowania wyników. Dzięki temu w ostatecznej analizie, można było się posłużyć całościowym modelem, na który składały się wszystkie badane dziewięć sfer. Dobór szczegółowych zagadnień, odbywał się z uwzględnieniem założeń do metodologii holistycznej edukacji środowiskowej. Zgodnie z tą metodologią uwzględniona została cała problematyka środowiskowa. Analizie zostały poddane, podstawowe układy mające charakter holistyczny. Przez układy takie, należy rozumieć zjawiska wykraczające niejednokrotnie poza obszar danej problematyki badawczej, ale znajdujące się w obrębie ekosystemów. Zasada ta oczywiście, nie dotyczyła globalnych pojęć systemowych typu: uniformitaryzm, katastrofizm, aktualizm geologiczny, prawo Dollo, zasada Eltona itp. Ta część projektu, została zaprojektowana $\mathrm{w}$ taki sposób, aby móc zbadać faktyczny stopień zrozumienia ciągłości, a zarazem przyczynowości występowania zjawisk środowiskowych. Bardzo ważną rolę, odegrały tu prawidłowo zestawione holistyczne zjawiska w obszarze pojęć ekologicznych. 
Wybrane aspekty metodyki badań holistycznej edukacji środowiskowej w świetle idei...

Ekologia, dzięki przyjętej metodologii, jak na razie najlepiej umożliwia zrozumienie występowania procesów środowiskowych na poziomie holistycznym. Dodatkowym atutem tego podejścia jest łączenie w ramach jej metodologii zjawisk, które występują na pograniczu środowiska abiotycznego i biotycznego. Badania wykazały, pewne zrozumienie dla istnienia współzależności wzajemnych relacji dla tych elementów środowiska przyrodniczego. Dotyczy to również problemów funkcjonowania biocenoz w skali czasowej. Problemy ich zmienności, stabilności, czy też efektu starzenia się są coraz lepiej rozpoznawane. Jest to istotne, przede wszystkim od strony praktycznej, gdzie trudno sobie wyobrazić w najbliższej przyszłości, aby proces zarządzania środowiskiem przyrodniczym realizowany poprzez takie narzędzia, jak idee zrównoważonego rozwoju, mógł się dalej odbywać, bez dogłębnej znajomości, tak podstawowych zjawisk występujących w środowisku.

W tej części badania, najsłabsze rozumienie odnotowane zostało dla procesów związanych z funkcjonowaniem łańcuchów troficznych oraz przepływu materii i energii. Braki w tym względzie, okazuje się, że mają swój wpływ również na rozumienie wielu zjawisk, dla których przepływy materii i energii, stanowią podstawę funkcjonowania. Dla tej części badawczej wyliczony został wskaźnik wiedzy na poziomie 45,4 (ze 100 możliwych do uzyskania), co stanowi bardzo słaby wynik, świadczący o daleko idącym mereologicznym podejściu również do tej części procesu edukacji ekologicznej. Podejście to prawdopodobnie wynika z faktu, że proces edukacji ekologicznej, odbywa się jednak poprzez pryzmat biologii, narzucającej swój punkt widzenia na ten przedmiot i sposób jego nauczania. Pewnym zaskoczeniem jest również fakt, bardzo słabego zrozumienia dla zjawisk związanych z warunkami dla istnienia życia, różnorodności gatunkowej, czy trochę bardziej skomplikowanych procesów w postaci mutualizmu przemysłowego. W tym wypadku za fakt ten, nie należy winić jedynie samej ekologii ze swoją metodologią. W obowiązujących programach nauczania akademickiego na kierunkach Ochrona Środowiska, trudno jest znaleźć problematykę, która by realizowała zamknięty program metodyczny ukierunkowany na problematykę warunków środowiskowych w stosunku do potrzeb organizmów. Przedmiot, który jest najbliższy tym zagadnieniom, a mianowicie Toksykologia wykładany jest nie na wszystkich kierunkach środowiskowych.

W zrealizowanych badaniach widoczny jest istotny brak wiedzy holistycznej w stosunku do zmieniających się potrzeb organizmów. Jest to bardzo ważny element edukacji środowiskowej z punktu widzenia również rozumienia, takich procesów, jak: ewolucjonizm czy kreacjonizm. Studenci o profilu kształcenia uniwersyteckim, posiadają tutaj naturalną przewagę wiedzy nad pozostałymi profilami kształcenia środowiskowego, szczególnie profilem inżynierskim.

Bardzo ważnym elementem dla analizy procesu holistycznej edukacji środowiskowej jest rozumienie pojęć systemowych dotyczących, problematyki za- 
chowania stabilności poszczególnych systemów środowiskowych. Prawidłowa interpretacja procesów wchodzących w skład tej części analizy, świadczy o umiejętności prognozowania systemowego na podstawie wiedzy pochodzącej z odrębnych dziedzin nauk podstawowych. Wskaźnik wiedzy dla tej grupy, nie przekroczył 54,2 (ze 100 możliwych do uzyskania), co ponownie świadczy o dość słabym rozumieniu zagadnień procesowych w środowisku. Szczególnie jest niska wiedza w zakresie roli parametrów środowiskowych, ich potencjalnej zmienności na funkcje życiowe organizmów. Niepokojąca jest daleko idąca nieumiejętność porównywania ze sobą parametrów funkcjonowania ekosystemów. Wiąże się z tym, zjawisko stabilności ekosystemów oraz cała problematyka, wpływu antropopresji na środowisko przyrodnicze. W całej tej części badawczej, najlepiej wypadło badanie wiedzy w zakresie znaczenia wpływu energii zewnętrznej na przebieg zasadniczych procesów ziemskich. Znacznie gorzej, było już z rozpoznawaniem przepływu energii i materii w ramach samych ekosystemów. Prawie zupełnie niezrozumiałe okazały się mechanizmy kompensowania parametrów środowiskowych przez morza i oceany i bynajmniej, nie chodzi tu jedynie o kwestie związane $\mathrm{z}$ klimatem.

Najsłabiej wypadło badanie wiedzy studentów w zakresie pojęć systemowych, dotyczących problematyki działalności człowieka na systemy środowiskowe. Wskaźnik wiedzy dla tej grupy, wyniósł zaledwie 34 (ze 100 możliwych do uzyskania). W ramach tej grupy badawczej najwyższe rozumienie, występuje wokół problematyki związanej z rolą dwutlenku węgla w procesach środowiskowych. Pozostała wiedza w tej grupie tematycznej jest rozpoznawana jedynie hasłowo, przy bardzo niskim rozumieniu procesów odpowiedzialnych za degradację środowiska. Brak jest rozumienia przyczynowo skutkowego, działalności człowieka na środowiskowo przyrodnicze. W tej grupie badawczej, najlepiej jest widoczne jednostronne podejście mereologiczne do procesu nauczania problematyki w zakresie ochrony środowiska. Odrębność oraz swoista „zamkniętość metodyczna" przedmiotów podstawowych w edukacji jest w tym przypadku, najlepiej widoczna. Brak umiejętności myślenia procesowego, w którym proces analizy obejmowałby całe zjawisko, bez względu na istniejący podział według dyscyplin naukowych jest podstawową słabością współczesnego systemu kształcenia akademickiego w ochronie środowiska. Słabość ta ma szczególne swoje odzwierciedlenie w kształtowaniu, a następnie wdrażaniu idei zrównoważonego rozwoju.

Znacznie wyżej, ale również poniżej zakładanego minimum progowego, wypadły wyniki w badaniu wiedzy w zakresie pojęć obejmujących swoim zasięgiem problematykę związaną z morzami i oceanami. W badaniu tym studenci uzyskali wartość wskaźnika wiedzy na poziomie 57,3 (ze 100 możliwych do uzyskania). Analiza uzyskanych danych, ponownie dowodzi o zbieżnej tendencji, istniejącej w całym projekcie badawczym, polegającej na pewnej znajomości definicji i oderwanych pojęć $\mathrm{z}$ daleko idącą nieumiejętnością przeprowadzania analizy systemowej 
Wybrane aspekty metodyki badań holistycznej edukacji środowiskowej w świetle idei...

procesów przebiegających w sposób definiowany jako holistyczny. Nieumiejętność analizy procesu ciągłości występowania na Ziemi takich ekosystemów, jak: oceany i morza, widoczna jest nie tylko z punktu widzenia aktualnie przebiegających w nich procesów fizycznych, chemicznych, czy biologicznych, ale również w związku z historią ich powstania. W ujęciu historycznym, bardzo ciekawy jest fakt, dlaczego nikt $\mathrm{z}$ badanych studentów, nie umiał wskazać żadnego źródła pochodzenia wody na Ziemi. Wody, z której powstały następnie morza i oceany. Fakt ten świetnie wpisuje się $\mathrm{w}$ jedną z postawionych $\mathrm{w}$ tej pracy wcześniej hipotez, dowodząc tym samym, bardziej mereologicznego podejścia do procesu edukacji środowiskowej, niż holistycznego.

Bardzo zbliżony wynik wskaźnika wiedzy, został uzyskany w badaniu wiedzy w zakresie pojęć systemowych, dotyczących szeroko rozumianej geologii Ziemi. W tym wypadku, wskaźnik wiedzy wyniósł wartość 54,2 (ze 100 możliwych do uzyskania). Struktura pytań w tej części badania w dość precyzyjnym stopniu, mogła wykazać poziom w zakresie rozumienia przebiegu procesów, odbywających się w skali czasu, odmierzanych rytmem geologicznym. Okazało się, że te stosunkowo nie najbliższe nam, ale niezwykle istotne dla obecnego funkcjonowania wielu ekosystemów w naszym kraju, procesy lodowcowe (przebiegające w plejstocenie), były najmniej zrozumiałe dla badanych studentów. W tej części projektu badawczego, wyraźnie widać brak zrozumienia dla następstwa procesowego, zjawisk decydujących o elementach budujących ekosystemy. Dotyczy to między innymi skały macierzystej, z której kształtują się następnie gleby.

Pomimo wprowadzenia do programu nauczania (na specjalności Ochrona Środowiska) podstaw Gleboznawstwa i Geologii, nie spowodowało to wyraźnej poprawy w wiedzy procesowej następstwa zjawisk środowiskowych. Dotyczy to na przykład, zarówno roli oddziaływania ostatnich zlodowaceń (w obszarze ich zasięgu) na funkcjonowanie ekosystemów przez nie ukształtowanych, jak i charakterystyki powstałej gleby (uzależnionej chociażby od ilości procentowej zawartości krzemionki, występującej w skale macierzystej). Wspomniane przykłady są niezwykle ważne, ponieważ nie tylko dowodzą zrozumienia występowania ciągłości procesów środowiskowych, ale mają one również bezpośredni wpływ na kondycję ekosystemów z punktu widzenia ich potencjalnej odporności na procesy degradacji.

W projekcie został wydzielony osobny moduł badawczy w zakresie pojęć systemowych, dotyczących problematyki związanej z litosferą. W badaniu tym, wskaźnik wiedzy wyniósł zaledwie 43,2 (ze 100 możliwych do uzyskania). Wyniki badań potwierdzają analizę z poprzedniego modułu badawczego. Od strony obowiązującej metodyki nauczania geologii, studenci posiadają niezbędną wiedzę w zakresie systematyki skał, czy genezy ich powstania. Nie potrafią jednak tych wiadomości, przełożyć na wiedzę stosowaną. Nie odróżniają roli, jaką mogą pełnić skały osadowe $\mathrm{w}$ porównaniu $\mathrm{z}$ innymi typami skał $\mathrm{w}$ budowie powierzch- 
ni pokrycia terenu. Konsekwencje tego stanu niewiedzy u badanych studentów, będą z pewnością widoczne w przyszłości po podjęciu pracy w zawodzie, kiedy to będzie trzeba zacząć podejmować właściwe decyzje w procesie zarządzania środowiskiem przyrodniczym.

Najwyższy wskaźnik wiedzy uzyskany został w module badawczym dotyczącym pojęć systemowych związanych z Atmosferą. W badaniu tym wskaźnik wiedzy, wyniósł prawie dostateczną wartość (70) tzn. 66,6 (ze 100 możliwych do uzyskania). Decydujące znaczenie za uzyskany dość dobry wynik w tej części badania, mają pozytywne rezultaty z grupy zagadnień, dotyczących procesów związanych $\mathrm{z}$ występowaniem tlenu w atmosferze. Systemowe myślenie w tej części badanych zagadnień, związane jest prawdopodobnie z pozycją, jaką zajmuje ta problematyka $\mathrm{w}$ edukacji $\mathrm{w}$ ramach realizowanego programu nauczania biologii. Tlen omawiany jest $\mathrm{w}$ wielu konfiguracjach programowych. Często przeprowadzane są również różnorodne ćwiczenia. To wszystko ma prawdopodobnie swój bezpośredni wpływ na uzyskane wyniki w tej części badania. Znacznie gorzej, wygląda już monitorowana wiedza w momencie, kiedy dochodzi do analizy występowania tlenu $\mathrm{w}$ atmosferze $\mathrm{w}$ ujęciu historycznym (dotyczy to, przede wszystkim problematyki dynamiki zmienności występowania tego pierwiastka w atmosferze itp.).

Ostatnią dziewiątą zdefiniowaną sferą badawczą, była grupa pojęć systemowych związanych z Pedosferą. Pojęcie pedosfery zostało celowo zastosowane, ponieważ już samo jego użycie odpowiada za określoną grupę procesów glebotwórczych, przebiegających $\mathrm{w}$ powierzchniowej warstwie skorupy ziemskiej. $\mathrm{W}$ dodatku jest to jeden $\mathrm{z}$ najważniejszych komponentów ekosystemów lądowych i wodnych. ${ }^{9} \mathrm{~W}$ badaniu tej sfery wskaźnik wiedzy wyniósł wartość 53,6 (ze 100 możliwych do uzyskania). Uzyskana wartość, świadczy o słabej wiedzy badanych studentów w zakresie procesów środowiskowych, przebiegających w tym elemencie środowiska. W tej części badania jest wyraźnie widoczny, nie zadawalający stan wiedzy, zarówno na poziomie mereologicznym, jak holistycznym. Stan ten skutkuje błędnymi wnioskami, jakie są wyciągane przez badanych w stosunku do tej sfery, jako pewnej całości układu środowiskowego. Rezultatem takiego myślenia jest wyciąganie szeregu błędnych wniosków, polegających między innymi na tym, że pedosferę traktuje się, jako „pomnażalne” zasoby kuli ziemskiej, co jest już na samym wstępie istotnym błędem merytorycznym. Skutkuje to szeregiem niezrozumiałych decyzji, które są podejmowane w procesie zarządzania środowiskiem w stosunku do ekosystemów, traktując w nich pedosferę, jako zasoby odnawialne. Konsekwencje takich decyzji są widoczne obecnie, nie tylko w krajach wysoko uprzemysłowionych, ale również i w tych, dla których wszystkie zasoby natury są jedynie elementem, służącym do zdobywania kolejnych celów politycznych.

S. ZAWADZKI, red., Gleboznawstwo, Wydawnictwo PWRiL, Warszawa, s. 559, 1999. 
Wybrane aspekty metodyki badań holistycznej edukacji środowiskowej w świetle idei...

Badanie tego elementu sfery dowiodło również, daleko idącej słabości w rozumieniu roli pedosfery, jako swoistego czynnika buforującego w stosunku do postępującego procesu antropopresji. Pomimo wprowadzenia do akademickiego programu nauczania dla badanych studentów wielu elementów stanowiących ważne ogniwa wiedzy $\mathrm{w}$ rozumieniu procesowych zjawisk odpowiedzialnych za degradację pedosfery, wiele czynników okazało się, że jest w dalszym ciągu niewystarczająco rozpoznawalnych. Dotyczy to między innymi, roli frakcji granulometrycznej w procesach środowiskowych, $\mathrm{pH}$, roli substancji organicznej, pojemności sorpcyjnej, czy też roli skały macierzystej itp. Znajomość tych zagadnień jest niezwykle ważna, nie tylko z punktu widzenia wiedzy merytorycznej, ale przede wszystkim w związku z potencjalnym prawidłowym wykorzystaniem pedosfery do potrzeb człowieka przy konstruowaniu metodologii dla idei zrównoważonego rozwoju.

Globalny wskaźnik wiedzy dla całości projektu badawczego wyniósł 50,39 (na 100 możliwych do uzyskania). Oczywiście badanie to w żadnym wypadku, nie wyczerpuje problematyki, która powinna być ujęta w tego typu analizie. Tym niemniej, wyniki tych badań stanowią wystarczający wyjściowy materiał do przeprowadzenia wstępnej analizy skali wiedzy i umiejętności holistycznego myślenia o zjawiskach zachodzących w środowisku przyrodniczym wśród badanej grupy studentów. Uzyskany wskaźnik wiedzy, nie jest wprawdzie do końca miarodajny, ponieważ, badani studenci częściowo w ramach realizowanego na UKSW programu akademickiego 2006/2007 (na kierunku Ochrona Środowiska), mieli wprowadzone w toku studiów, pewne elementy systemowej analizy środowiskowej w ramach takich podstawowych przedmiotów, jak: Hydrologia, Geologia, Ekologia czy Gleboznawstwo. Globalny wskaźnik wiedzy na poziomie 50,39 dowodzi, że końcowy efekt tych działań, nie znalazł jednak swojego odbicia w uzyskanych wynikach.

Działania te natomiast widoczne, były podczas szczegółowej analizy 105 projektów badawczych, składających się na całość analizy holistycznej wiedzy o środowisku przyrodniczym. Część z nich w postaci 26 bloków tematycznych (pomimo dużej dozy ich skomplikowania), została jednak w miarę poprawnie zinterpretowana. Zebrane wyniki badań obrazują jednak wśród badanych studentów, całkowicie rozproszony stan wiedzy środowiskowej.

Analiza wszystkich badanych sfer pod kątem uzyskanego poziomu wiedzy wskazuje, że żaden z bloków tematycznych składających się na dziewięć badanych sfer, nie uzyskał zdefiniowanego minimum progowego. Najbliższym tego minimum, okazał się blok pojęć uwzględniający problematykę holistyczną w zakresie pojęć systemowych związanych $\mathrm{z}$ atmosferą, natomiast najdalszym blok pojęć systemowych w zakresie problematyki działalności człowieka na systemy środowiskowe. Wynik ten, ponownie utwierdza w przekonaniu o daleko idących trudnościach w dokonywaniu przez badanych, analizy systemowej procesów śro- 
dowiskowych. Właśnie w tej sferze badawczej, należało się wykazać umiejętnością analizy holistycznej procesów środowiskowych. Brak umiejętności prowadzenia takiej analizy dowodzi tego, że badani studenci, ciągle jeszcze przede wszystkim gromadzą wiedzę w rytmie mereologicznym, nie posiadając w oparciu o tę bazę danych, niezbędnej wiedzy holistycznej o środowisku przyrodniczym. Wiedzy, która decyduje o umiejętnościach w prawidłowym zarządzaniu środowiskiem oraz kształtowaniu oraz wdrażaniu idei zrównoważonego rozwoju.

Ciekawym uzupełnieniem przedstawionych analiz danych liczbowych są wyniki badań, porównujące stan wiedzy w zakresie znajomości problematyki globalnych pojęć systemowych oraz pojęć systemowych, ale dotyczących wyłącznie konkretnych sfer środowiskowych. $Z$ otrzymanych danych wynika, trochę niższy poziom wiedzy w zakresie globalnych pojęć systemowych, tym niemniej, nie jest to różnica dość znaczna (wartości zbadane 45/55). Ta różnica wynika prawdopodobnie z faktu, że badani studenci w realizowanym programie edukacji środowiskowej, mają już wprowadzoną pewną ilość przedmiotów o charakterze humanistycznym (filozofia przyrody, ekofilozofia itp.). W ramach tych przedmiotów, poruszają wielokrotnie kwestie związane z problematyką pojęć o charakterze globalnym. Wiedza ta z pewnością w ogólnym wykształceniu jest, nie mniej ważna od wiedzy tzw. empirycznej. Wartością najbardziej poszukiwaną dla prawidłowego procesu holistycznej edukacji środowiskowej, powinno być wyrównywanie tych dwóch sfer wiedzy o globalnych procesach przebiegających w środowisku przyrodniczym.

Jak widać z wcześniejszych rozważań, nie ma możliwości wypracowania poprawnego systemu holistycznej edukacji środowiskowej jedynie w oparciu o samą empirię. Należy w tym miejscu stwierdzić, że nawet proces ukierunkowania dalszego rozwoju samej empirii, powinien w dużej mierze odbywać się z uwzględnieniem sposobu postrzegania świata przez humanistów w tym ekofilozofów. Odejście od tej formuły, może spowodować w ostatecznym efekcie, zdominowanie myślenia poprzez kategorie czysto ekonomiczne. Podważy to również podstawowe ideologiczne fundamenty dla założeń zrównoważonego rozwoju, prowadząc tym samym do dysharmonii pomiędzy człowiekiem a naturą. Proces taki miałby również swój wymiar w kształtowaniu świadomości ekologicznej. Nie można zapominać, że cały proces holistycznej edukacji środowiskowej jest realizowany właśnie z myślą o budowie konstruktywnego systemowego programu edukacji holistycznej, prowadzącego do świadomego proekologicznego myślenia o środowisku i procesach $\mathrm{w}$ nim zachodzących, a nie kolejnej wyłącznie jego analizy. Badanie stanu holistycznej edukacji z jednej strony ma przynieść, nie tylko nowe rozwiązania w zakresie samej metodyki jej realizacji, ale również dostarczyć niezbędnej wiedzy w zakresie budowy interdyscyplinarnego systemu holistycznej edukacji środowiskowej.

W prawidłowym konstruowaniu procesu holistycznego rozumienia środowiska przyrodniczego z pewnością, istotne znaczenie ma, nie tylko brak inter- 
Wybrane aspekty metodyki badań holistycznej edukacji środowiskowej w świetle idei...

dyscyplinarnej platformy metodologicznej, tworzącej płaszczyznę do badań nad procesami zachodzącymi w środowisku przyrodniczym, ale również często dość rozbieżne działania $\mathrm{w}$ kontakcie człowieka $\mathrm{z}$ naturą. Wieloletnie traktowanie środowiska przyrodniczego, jako niewyczerpanego rezerwuaru zasobów środowiskowych ciągle odgrywa tu swoje piętno. Dlatego też poszukiwanie właściwej metodyki dla wymiaru holistycznej edukacji środowiskowej w obecnych czasach nabiera specjalnego znaczenia.

\section{Piśmiennictwo}

SANDNER J., Wybrane aspekty procesów środowiskowych holistycznej edukacji przyrodniczej w świetle idei zrównoważonego rozwoju, Problemy Ekorozwoju, vol. 3, Nr 2, s. 69-80, 2008.

Tyвurski W., Powstanie i rozwój filozofii ekologicznej, Problemy Ekorozwoju, Lublin, vol. 1, Nr 1, s. 7-15, 2006.

LEopold A., A sand county almanac and sketches here and there, 1949, przekład; Zapiski z piaszczystej krainy, przedmowa Okraska-Bystrak, Bielsko-Biała 2004, za Tyburski W., Problemy Ekorozwoju nr 1, 2006.

Rolston III H., Environmental Ethics, Wydawnictwo Temple University Press, s. 408, 1989.

Naess A., Ecology, Community and Lifestyle, Wydawnictwo Cambridge University Press, s. 223, 1993.

SAnDner H., Człowiek i przyroda, Wiedza Powszechna, wyd. I, Warszawa, s. 273, 1972.

SкоLıмоwsкi H., Filozofia żyjąca. Ekofilozofia jako drzewo życia, Wydawnictwo Pusty Obłok, s. 106-110, 1993.

SANDNer J., Environmental protection concept in holistic nature studies education, Studia Ecologiae et Bioethicae, t. 4/2006, Wydawnictwo UKSW, Warszawa, s. 377-383, 2006.

ZAWADZKi S., red., Gleboznawstwo, Wydawnictwo PWRiL, Warszawa, s. 559, 1999. 


\title{
Selected aspects of research methodology of a holistic educational environment in the light of the idea of sustainable development
}

\begin{abstract}
SUMMARY
The concept of the balanced development idea caused a renewed view on the problems in the area of the research methodology in environmental education. The aforesaid view is related to the necessity of implementing methods in which an appropriate place will be found for a holistic approach to occurring environmental processes. An approach enabling interdisciplinarity of this problem will finally find its solution also in a new teaching method. This forces a new quality of a perceptive view of the environment, however by no means severing from the accepted research methodology enforced in nature sciences.

The devised and generated uniformed standardization of holistic environmental education methodology, philosophy of ecology and environmental ethics, should, as a result, impact not only the knowledge status on the said problem but also create quintessential basics in execution of research on the process of shaping the pro-ecology approach.

The article also includes selected comments on the studies on estimation methods of the holistic nature science education, which were carried out in the 2006/2007 academic year at the Institute of Ecology and Bioethics of the UKSW (Cardinal Stefan Wyszynski University.) The objective of the aforesaid studies, among others, was to work out new system solutions, which could be implemented into the academic teaching programs of the Environmental Protection study specialization. They should also become a reason for a discussion on research methodology for the final individual assignation of "Environmental Protection" studies in our country.
\end{abstract}

